\title{
Alien plant invasions in tropical and sub-tropical savannas: patterns, processes and prospects
}

\author{
Llewellyn C. Foxcroft • David M. Richardson • \\ Marcel Rejmánek $\cdot$ Petr Pyšek
}

Received: 16 December 2009/Accepted: 19 March 2010/Published online: 11 July 2010

(C) The Author(s) 2010. This article is published with open access at Springerlink.com

\begin{abstract}
Biological invasions affect virtually all ecosystems on earth, but the degree to which different regions and biomes are invaded, and the quality of information from different regions, varies greatly. A large body of literature exists on the invasion of savannas in the Neotropics and northern Australia where invasive plants, especially African grasses, have had major impacts. Less has been published on
\end{abstract}

L. C. Foxcroft ( $\square)$

Scientific Services, South African National Parks, Private Bag X402, Skukuza 1350, South Africa

e-mail: LlewellynF@sanparks.org

L. C. Foxcroft - D. M. Richardson

Centre for Invasion Biology, Department of Botany and Zoology, Stellenbosch University, Private Bag X1, Matieland 7602, South Africa

e-mail: rich@sun.co.za

M. Rejmánek

Department of Evolution and Ecology, University of California-Davis, Davis, CA 9516, USA

e-mail: mrejmanek@ucdavis.edu

P. Pyšek

Department of Invasion Ecology, Institute of Botany, Academy of Sciences of the Czech Republic, Průhonice 252 43, Czech Republic

e-mail: petr.pysek@ibot.cas.cz

P. Pyšek

Faculty of Sciences, Department of Ecology, Charles University, Viničná 7, 12844 Prague 2, Czech Republic plant invasions in African savannas, except for those in South Africa. Negative impacts due to plant invasions in African savannas appear to be less severe than in other regions at present. As savannas cover about $60 \%$ of the continent, with tens of millions of people relying on the services they provide, it is timely to assess the current status of invasions as a threat to these ecosystems. We reviewed the literature, contrasting the African situation with that of Neotropical and Australian savannas. A number of drivers and explanatory factors of plant invasions in savannas have been described, mostly from the Neotropics and Australia. These include herbivore presence, residence time, intentional introductions for pasture improvements, fire regimes, the physiology of the introduced species, and anthropogenic disturbance. After comparing these drivers across the three regions, we suggest that the lower extent of alien plant invasions in African savannas is largely attributable to: (1) significantly lower rates of intentional plant introductions and widespread plantings (until recently); (2) the role of large mammalian herbivores in these ecosystems; (3) historical and biogeographical issues relating to the regions of origin of introduced species; and (4) the adaptation of African systems to fire. We discuss how changing conditions in the three regions are likely to affect plant invasions in the future.

Keywords Africa - Biological invasions .

Cerrado $\cdot$ Llanos $\cdot$ Non-native $\cdot$ Species lists 


\section{Introduction}

Savannas form one of the world's largest biomes and are the dominant vegetation type in Africa (Scholes 1997), occupying about $65 \%$ of the continent (Huntley and Walker 1982). About a fifth of the global human population and a large proportion of the world's ungulates (wild and livestock) are found in savannas (Lehmann et al. 2009). A wealth of knowledge now exists on the composition and function of savannas, particularly in Africa (see Sinclair and Norton-Griffiths 1979; Huntley and Walker 1982; Bourlière and Hadley 1983; Cole 1986; Werner 1991; Scholes and Walker 1993; Sinclair and Arcese 1995; Solbrig et al. 1996; Cowling et al. 1997; Coe et al. 1999; du Toit et al. 2003; Sankaran et al. 2005, 2008; Furley 2006; Shorrocks 2007; Sinclair et al. 2008). This includes a growing understanding of the inherent complexity of savanna systems, and the extent that savannas depend on complex interactions of climatic and edaphic factors, and disturbance from both fire and herbivory (Sankaran et al. 2005, 2008). Globally, the tropical savannas are the second largest biome, extending over $15 \times 10^{6} \mathrm{~km}^{2}$ (Long et al. 1989; Melillo et al. 1993).

Savannas are defined as a tropical vegetation type co-dominated by a largely continuous layer of grasses (generally below $2 \mathrm{~m}$ ) and a discontinuous woody tree layer (Bourlière and Hadley 1983; Scholes 1997; Scholes and Archer 1997). A common feature of all savannas is the hot wet season and warm dry season (Scholes 1997), an usually high fire frequency (Huntley 1982; Scholes 1997), and high habitat heterogeneity (Pickett et al. 2003; Rogers 2003; Tongway and Ludwig 2005). Savannas vary spatially in composition and function across a number of scales (Bourlière and Hadley 1983). For example, there is high variation along soil gradients and associated vegetation at the scale of catenas, or across a variety of sub-savanna type habitats in the sub-Saharan region (see Fig. 1.9 in Shorrocks 2007). Within this spatial arrangement, savannas vary structurally, from a short grass layer with tall trees, to savannas with a range of shrub and tree sizes in between (e.g. Pivello et al. 1999a). Temporally, savannas and grasslands have varied in extent and distribution, from glacial/interglacial cycles (Dupont et al. 2000) to the last few hundred years (Gillson 2004).
Many millions of people depend on savannas for their livelihoods, leading to a wide range of land uses, such as agriculture, grazing and agroforestry, including fuel wood harvesting (Huntley 1982; Scholes 1997; van Wilgen et al. 2001). Therefore savannas are subject to many kinds of anthropogenic disturbances, as well as periodic natural disturbances (fire, drought, floods, mega-herbivores; Walker and Noy-Meir 1982; Scholes 1997). Anthropogenic disturbances create habitats and conditions suitable for invasions by alien plants, thus forming multiple sources for further invasions into savanna systems (van Wilgen et al. 2001). The Millennium Ecosystem Assessment (2005) assessed the past and current impact of five drivers of ecosystem change for a range of biomes. For the tropical grassland and savanna biome, invasive species were regarded to have had a relatively low impact over the last century, but a trend of very rapid increase of the impact for this biome was noted. The current low incidence and influence of invasive plants in savannas relative to some other terrestrial biomes may be related to the fact that disturbance, which generally favours invasions, is fundamental to savanna functioning. Savannas are generally resilient to changes in disturbance regimes (Walker and Noy-Meir 1982; Harrison and Shackleton 1999), possibly making them relatively resistant to biological invasions. Habitat modification has had a high impact and is increasing in importance; climate change has had a moderate but very rapidly increasing impact; overexploitation a very high and continuing impact; and pollution a moderate but very rapidly increasing impact in these biomes (Millennium Ecosystem Assessment 2005). Although invasive species are not currently the main threat to the conservation of biodiversity and functioning of tropical grasslands and savannas, they may well become much more widespread and influential in the future. Therefore, it seems prudent to review the current status of plant invasions in the savanna biome.

\section{Aims of the review and delimitation of terms}

This paper collates available literature on plant invasions in savannas, with an emphasis on those in Africa and compares the situation in this region with savanna systems elsewhere. As there is no 
over-arching global classification system for savannas (Scholes 1997), we contrast the situation in the African, Australian and Neo-tropical savannas using the broad definition of savanna (as described above). Finer scale classification systems are based on factors such as nutrient and moisture gradients and are frequently regionally specific (see Table 1 for definitions of various savanna systems). For example, in southern Africa, nutrient-rich, arid regions give rise to the fine-leaved (nanophyllous) savanna, while the nutrient poor, moister regions give rise to the broadleaved (mesophyllous) savannas (Scholes 1997 and Table 1). Although there may be differences in the presence of alien plants found in the different savanna types (for example in the fine-leaved or broadleaved savannas), the scale of this review and the dearth of information from the different regions precludes such fine-scale assessment at this stage. However, as this is the first assessment of alien plants in tropical savannas globally, the elucidation of broad patterns should be instructive.

To describe the levels of invasion of alien species invasions in savannas, we use the terms proposed by Richardson et al. (2000) and Pyšek et al. (2004). These include a range of terms which denote the status of introduced species at stages along the "naturalization-invasion continuum" (Pyšek and Richardson 2006), according to which species may be termed casual, naturalized, or invasive by invoking biogeographical criteria. Of most concern are transformer species, defined as a subset of invasive plants which change the character, condition, form, or nature of ecosystems over a substantial area relative to the extent of that ecosystem (Richardson et al. 2000).

In savannas, the terms "invasion" and "bush encroachment' are sometimes used interchangeably. Bush encroachment involves the increase in abundance and density of native woody plant species (Archer et al. 1995; Hoffmann and Todd 2000; Roques et al. 2001; Asner et al. 2003; Wigley et al. 2009). This phenomenon has often been related to poor land management practices such as overgrazing by domestic livestock (Walker et al. 1981), changes in land-use (Bond 2008), and increased $\mathrm{CO}_{2}$ levels leading to tree encroachment and thickening in grassdominated systems (Bond and Midgley 2000; Bond 2008). In this review we focus on invasions by alien (non-native) species (see Pyšek et al. 2004 for definition) and do not deal with bush encroachment, where native woody species encroach to form dense, often monodominant, stands (for details on this phenomenon in North America, see Van Auken 2000).

It is also important to make a clear distinction between true savannas and artificial grasslands (pastures) in some cases when assessing plant invasions. For example, in Mexico artificial grasslands and natural savannas, from both tropical and temperate areas are usually lumped into a single category (pastizal). However, usually only artificial grasslands, created in places originally covered by woody vegetation, are heavily invaded by alien species (López-Olmedo et al. 2007).

\section{Alien plant invasions in African savannas}

The sparse information available in the literature on plant invasions in Africa suggests that invasions are not a major problem in these ecosystems (e.g. D'Antonio and Vitousek 1992). However, Henderson and Wells (1986) list 583 species of naturalised alien plants for tropical savannas in southern Africa, stating that 151 are known to be particularly aggressive invaders generally. More recently, 48 species were considered "prominent invaders" in the savanna biome of South Africa (Henderson 2007). Lantana camara L. was the most prominent species, followed by Chromolaena odorata (L.) R.M. King \& H. Rob. and Melia azedarach $\mathrm{L}$. The remaining of the top ten invasive species were, in order, Solanum mauritianum Scop., Acacia mearnsii De Wild., Opuntia ficusindica (L.) Miller, Ricinus communis L., Psidium guajava L. and Jacaranda mimosifolia D. Don. However, of this list most species are usually only found along rivers flowing through savannas and are therefore not invaders of true savanna ecosystems. Some species definitely do invade savannas in South Africa: Chromolaena odorata in Hluluwe-Imfolozi (Macdonald 1983), Opuntia stricta in Kruger National Park (Fig. 1b; Foxcroft et al. 2004; Foxcroft and Rejmánek 2007), and Prosopis spp., Schinus molle and several other alien trees and shrubs in arid savanna around Kimberley (Milton et al. 2007). While most alien plant species that are currently invasive in South Africa arrived in the region in the 1800 s, the invasion of grassland and savanna biomes by $O$. ficus-indica dates back to the 1770 s (Henderson 
Table 1 A typology of commonly used savanna related terminology

Term Geographical distribution

Cerrado Brazil

Caatinga Brazil

Llanos

Pastizal

Mexico

Pine savanna

(Blue) Oak savanna

Mesic savanna

Southern Africa
Meaning

The Brazilian cerrados comprise a gradient from the grassland form (named 'campo limpo') to a sclerophyllous woodland form (named 'cerradão'), where the herbaceous layer gives place to arboreal elements, and the most apparent variation is in tree density and height. The intermediate ecotonal scrub forms are: 'campo sujo', 'campo cerrado' and 'cerrado sensu stricto', in an increasing density of trees. In cerradão, the canopy cover is $\sim 30-60 \%$; in cerrado sensu stricto $\sim 30-40 \%$; in campo cerrado, $\sim 10 \%$; in campo sujo, up to $1 \%$, and there is no tree cover in campo limpo (Eiten 1972, 1983; Coutinho 1978, 1982 as in Pivello et al. 1999a; Huber and Riina 2003)

Caatinga is found in northeastern Brazil and has a characteristic semiarid climate with average precipitation of $800 \mathrm{~mm} / \mathrm{annum}$. The vegetation is largely xerophytic, spiny and caducifoliate (Cavalcante and Major 2006). The term Caatinga is means "white forest", and is often referred to as dry or scrub forest

Los Llanos (meaning the flat plains) is a vast tropical grassland plain situated at the east of the Andes in north-western South America. Because of infertile sandy soils and regular flooding, this area represents anomalously low plant species richness in the tropics (Barthlott et al. 1996; Huber and Riina 2003)

In the most commonly used classification of Mexican vegetation, all grassland types, both natural and induced, from both tropical and temperate regions, were clumped together into a single category - pastizal-meaning grassland (López-Olmedo et al. 2007; Huber and Riina 2003)

Characterized by an open canopy of pines (Pinus palustris P. Mill. and/or P. elliottii Engelm.) and a diverse understorey of grasses and forbs maintained by frequent fires. Further characteristics include wet soils of low $\mathrm{pH}$ and relatively low nutrients (King and Grace 2000)

An oak savanna is a plant community with scattered "open-grown" oaks. Other terms for these savannas are "oak openings" and "oak barrens". The savanna canopy ranges from about 10 to $50 \%$. In such a habitat, the ground layer receives dappled sun and shade, which permits growth of a wide diversity of grasses and flowering plants. This is one of the Californian communities that is most invaded by alien plant species (Rejmánek et al. 2005, Fig. 13.2).

Moist savanna systems, generally between 600 and $1500 \mathrm{~mm}$ rainfall per annum, found largely in the eastern parts of southern Africa; similar to fine leaved savanna (Scholes 1997) 
Table 1 continued

\begin{tabular}{|c|c|c|}
\hline Term & Geographical distribution & Meaning \\
\hline Arid savanna & Southern Africa & $\begin{array}{l}\text { Relatively arid regions with generally between } 400 \\
\text { and } 800 \mathrm{~mm} \text { rainfall per annum, found largely in } \\
\text { the western parts of southern Africa; similar to } \\
\text { broad leaved savanna (Scholes 1997) }\end{array}$ \\
\hline Fine leaved (nanophyllous) & Southern Africa & $\begin{array}{l}\text { Nutrient rich, arid regions give rise to the fine leaved } \\
\text { (nanophyllous) savanna (Scholes 1997) }\end{array}$ \\
\hline Broad leaved (mesophyllous) & Southern Africa & $\begin{array}{l}\text { Nutrient poor, moister regions give rise to the } \\
\text { broadleaved (mesophyllous) savannas (Scholes } \\
\text { 1997) }\end{array}$ \\
\hline Grass and shrub savanna & North and eastern Africa & $\begin{array}{l}\text { Savanna type stretching across northern Africa, from } \\
\text { northern Senegal and Mauritiana to Sudan. The } \\
\text { northern border (the Sahel) is dominated by } \\
\text { Acacia. It continues into the Acacia-Commiphora } \\
\text { savanna of the horn of Africa, eastern Ethiopia, } \\
\text { and east Africa as the Somali-Masai dry savanna } \\
\text { (Shorrocks 2007) }\end{array}$ \\
\hline Tree and shrub savanna & Central Africa & $\begin{array}{l}\text { Two separated blocks of vegetation, lying north and } \\
\text { south of the rainforest and miombo woodland } \\
\text { savannas of central Africa. The northern area is } \\
\text { dominated by Terminalia and Combretum trees } \\
\text { and shrubs, and Pennisetum purpureum grass. The } \\
\text { southern section is dominated by } \\
\text { Colophospermum mopane tree and shrubs } \\
\text { (Shorrocks 2007) }\end{array}$ \\
\hline Woodland savanna & Central/South Africa & $\begin{array}{l}\text { Two distinct blocks of savanna, namely, Miombo } \\
\text { (central/south Africa), which is dominated by } \\
\text { Brachystegia boehmii, and doka (in the north), } \\
\text { which is dominated by Isoberlinia doka } \\
\text { (Shorrocks 2007) }\end{array}$ \\
\hline Forest-savanna mosaic & Africa & $\begin{array}{l}\text { Encircles the tropical rainforest of the Congo basin, } \\
\text { forming the edge of the 'true' savanna. Highly } \\
\text { dynamic vegetation, interlacing forest, savanna } \\
\text { and grassland (Shorrocks 2007) }\end{array}$ \\
\hline Tropical savanna & Australia & $\begin{array}{l}\text { The Australian tropical savannas are landscapes of } \\
\text { dense grass and scattered trees that stretch across } \\
\text { northern Australia from Broome to Townsville. } \\
\text { They cover a huge area-around } 1.9 \text { million } \\
\text { square kilometres-or around a quarter of } \\
\text { mainland Australia's land area (Whitehead et al. } \\
\text { 2000) }\end{array}$ \\
\hline
\end{tabular}

Although not comprehensive of all terminology used in connection with savanna systems, these terms are commonly encountered in the literature. Although this list deals only with tropical and sub-tropical savannas, two commonly encountered savanna related terms from temperate North America are included for comparison

and Wells 1986). Within these biomes, river and stream banks which are frequently seasonally flooded are substantially more vulnerable to plant invasions than areas away from rivers (Henderson and Wells 1986; Foxcroft and Richardson 2003). Rivers and riparian habitats thus form important conduits of dispersal of alien plants from one area to another (Foxcroft et al. 2007; Richardson et al. 2007a). This is further supported in an economic review of alien plant control programmes in South Africa; Turpie (2004) indicates that the grassland and savanna biomes are extensively invaded, but mostly in the moister regions and particularly along river courses.

The savanna ecosystems in South Africa's Kruger National Park (KNP; 20,000 $\mathrm{km}^{2}$ ), have been the subject of a long-standing scientific investigation 

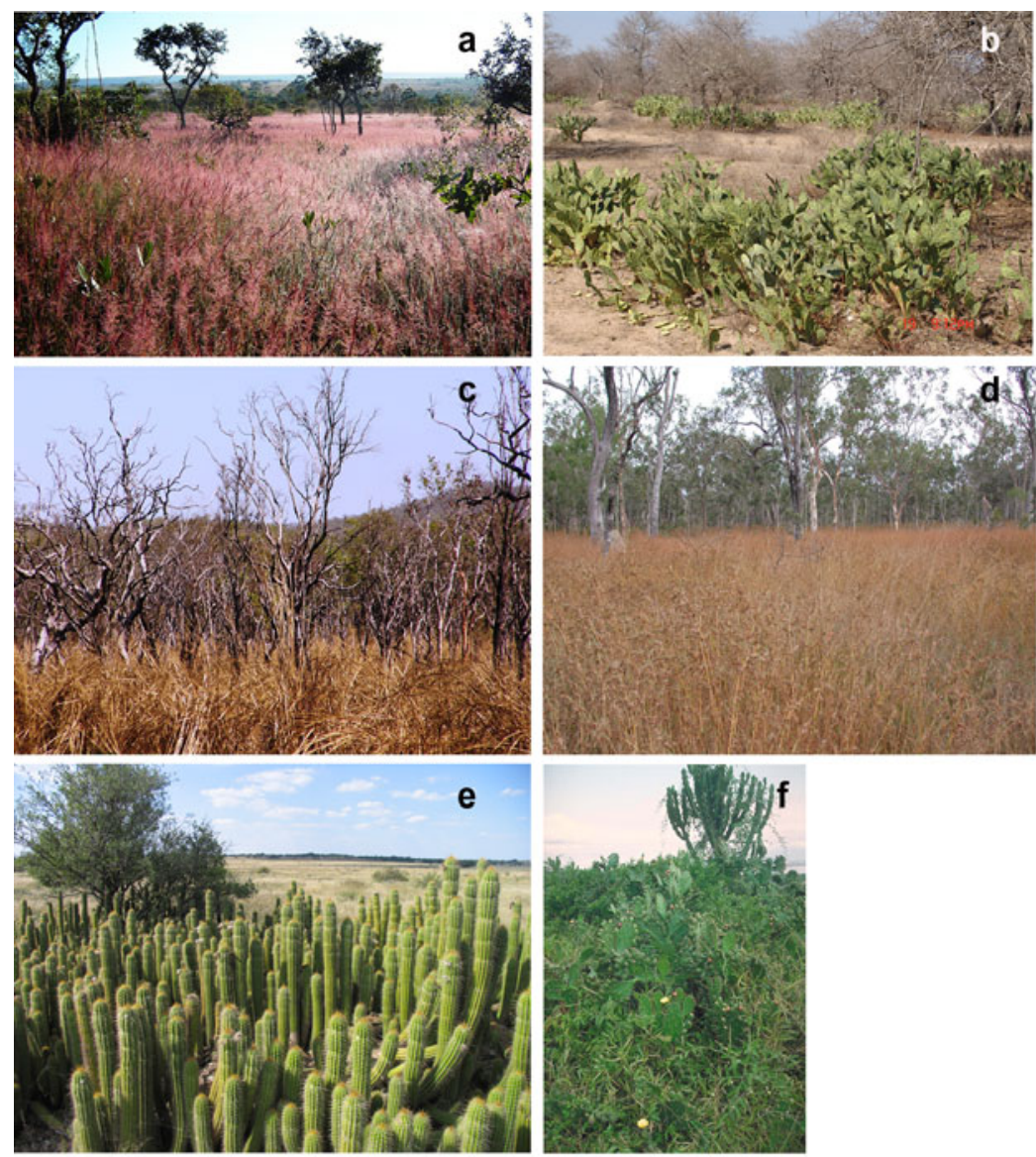

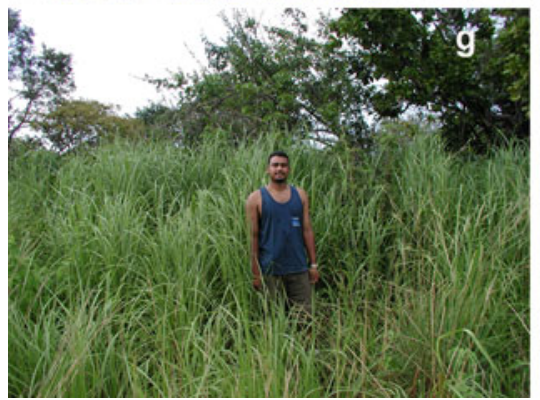

Fig. 1 Typical invasive species from the three regions covered in this review. a Melinis minutiflora (Poaceae; molasses grass) in the Neotropics. Photo $\mathrm{M}$ Carlos. b Opuntia stricta (Cactaceae; sour prickly pear) in Kruger National Park, South Africa. Photo LC Foxcroft. c Andropogon gayanus (Poaceae; gamba grass) in northern Australian savannas. Photo $\mathrm{S}$ Setterfield. d Themeda quadrivalvis (Poaceae; giant Kangaroo

(du Toit et al. 2003). Also, the invasion of alien plants in the KNP has been reasonably well studied (see e.g. Foxcroft and Richardson 2003; Freitag-Ronaldson and Foxcroft 2003; Foxcroft and Freitag-Ronaldson 2007 for a summary). The KNP currently maintains a

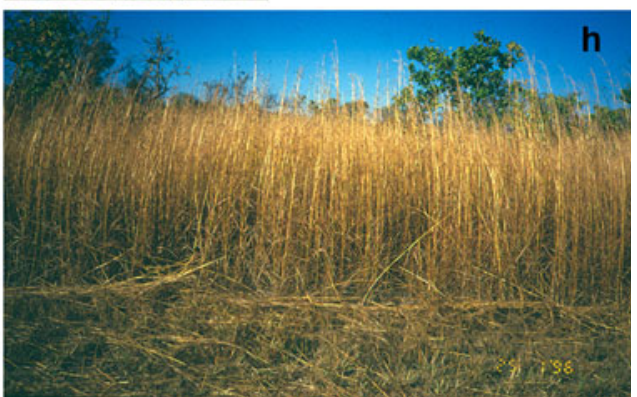

grass) near Cairns, Australia. Photo M. Rejmánek. e Echinopsis spachiana (Cactaceae; torch cactus) invading arid savanna in South Africa. Photo DM Richardson. f Opuntia monocantha (Cactaceae; drooping prickly pear) in Queen Elizabeth National Park, Uganda. Photo M. Rejmánek. g, h Hyparrhenia rufa (Poaceae; thatch grass) in the central savannas of Venezuela. Photo Z. Baruch

list of 373 alien plant species (Foxcroft et al. 2003, 2008; Foxcroft 2009), including invasive, aquatic, ruderal and ornamental species. However, Foxcroft et al. (2003) suggested that only 121 taxa were either invasive or potentially invasive, and more 
importantly, only two (L. camara and O. stricta) species were regarded as transformer species at that point. This was based on observations of large impenetrable thickets of $L$. camara along rivers excluding all other species, and of large stands of O. stricta in the Skukuza region. However, current levels of alien plant abundance have been substantially reduced since 2003 and maintained at a low level due to the ongoing control activities by the Working for Water programme (see Foxcroft and Freitag-Ronaldson 2007).

In Macdonald and Frame's (1988) synthesis of five protected areas in tropical savannas, few alien species were recorded. In the Serengeti-Ngorongoro ecosystem (Tanzania) the authors listed 12 introduced vascular plant species, of which they considered four to be substantial problems. The most problematic species at that time appears to have been Tagetes minuta L., which had replaced native grasses over an area of 10-15 ha. Euphorbia tirucalli L., which was listed among alien species (presumed to be introduced from India), has more recently been shown to be native to east and southern Africa (Carter and Radcliffe-Smith 1988; Germishuizen and Meyer 2003) and introduced to west Africa and India (Mies et al. 1996; Pandey 2000). In general it was thought that introduced plants were unimportant in the Serengeti ecosystem (Macdonald and Frame 1988). However, Lyons and Miller (1999) and Henderson (2002) listed 43 species of alien plants for the Ngorongoro crater. Belsky (1987) wrote that there was no indication that introduced weeds were colonizing natural disturbances or invading the undisturbed grassland community in Serengeti National Park. Foxcroft (2003) recorded 10 species of alien plants in the Seronera and western corridor areas of the Serengeti National Park. These included widespread stands of Opuntia stricta var. dillenii (Ker Gawl.) L. D. Benson and $O$. monocantha Haw. Among the approximately 1,300 vascular plant species known from the Mkomazi Game Reserve (Tanzania; 3,250 km², see Coe et al. 1999), only eight naturalized plant species were reported (Table 2).

Very little is known from other parts of Africa. However from published phytosociological studies it appears that savannas in the other regions of Africa are also only very rarely invaded by non-native plant species. For example, Schmitz (1971) reported Ageratum conyzoides, Amaranthus spinosus, Bidens pilosa, Sonchus asper, Solanum nigrum, Conyza bonariensis, Physalis peruviana, Eclipta prostrata, and Galinsoga parviflora as occasional aliens in disturbed savannas of Congo. Jeník and Hall (1976) reported only Azadirachta indica as occasionally growing in Accra Plains savannas, Ghana. Sillans (1958, p. 67) provided a short list of about 30 species introduced in savannas of western equatorial Africa. Unfortunately, it is impossible to say whether individual species are just casual, persisting after cultivation, or clearly naturalized. However, it is clear that none of them are transformer or dominant species.

To conclude, the picture that emerges from a study of the literature and our observations (see above and Table 2) suggests that in African savannas, despite the range of potentially invasible habitats, many forms of anthropogenic landuse over a long period (Bourlière and Hadley 1983), and high levels of frequent disturbances, invasive alien plants are not yet very widespread or common, and are a relatively minor component of habitat degradation and biodiversity loss. An important caveat however is that many woody alien species were introduced and widely planted for agroforestry only in last few decades, and many of these species are already naturalized and/or known to be invasive in some part of the world. Although problems with invasive species originating from agroforestry are not yet well reported, such problems are widespread throughout the tropics, including many parts of Africa (see Richardson et al. 2004 for a review). Species selected for agroforestry and practices associated with this landuse combine to create a perfect recipe for increasing invasions (e.g. mainly traits clearly associated with invasiveness; high propagule pressure, increasing time since introduction, improved climate matching; increased availability of mutualists, especially mycorrhizal fungi and nitrogen-fixing bacteria; Richardson et al. 2004).

\section{Alien plant invasions in Neotropical savannas}

Much work has been done on assessing the invasion of intentionally introduced species in the Neotropics, and data indicate that savannas in the New World are, at least locally, highly invaded (Parsons 1972). For example, Baruch and Bilbao (1999) report how African $\mathrm{C}_{4}$ grasses, introduced into Neotropical 


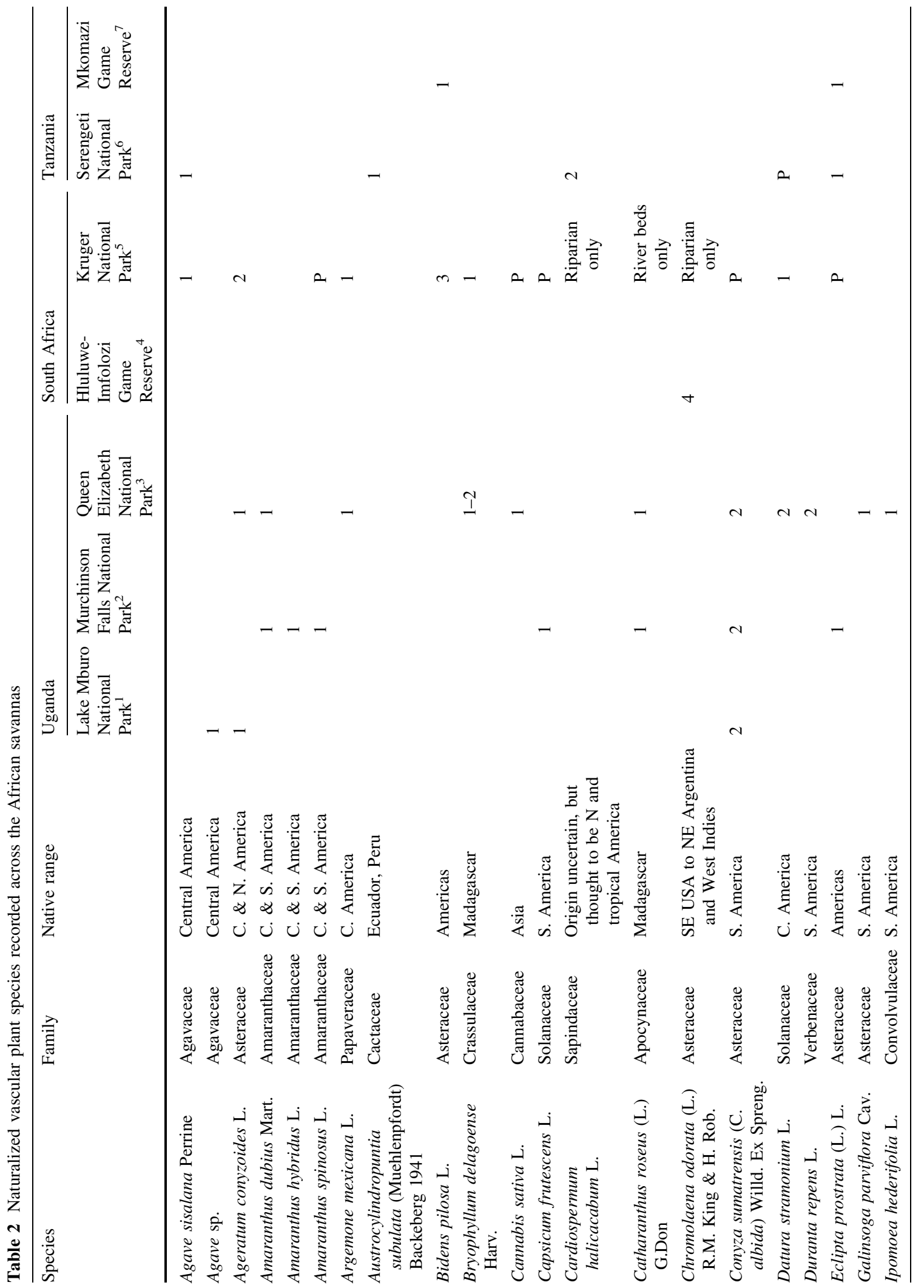




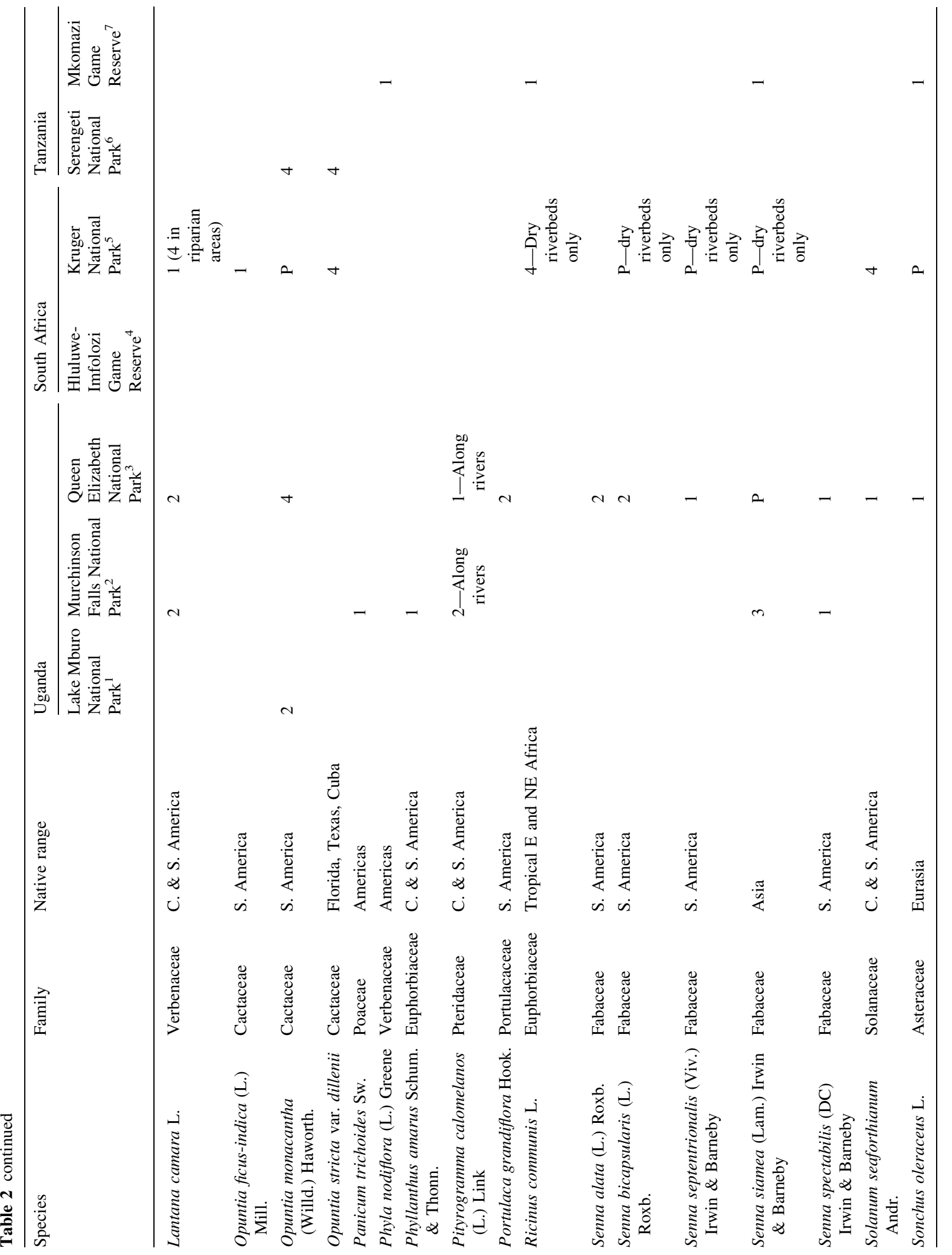




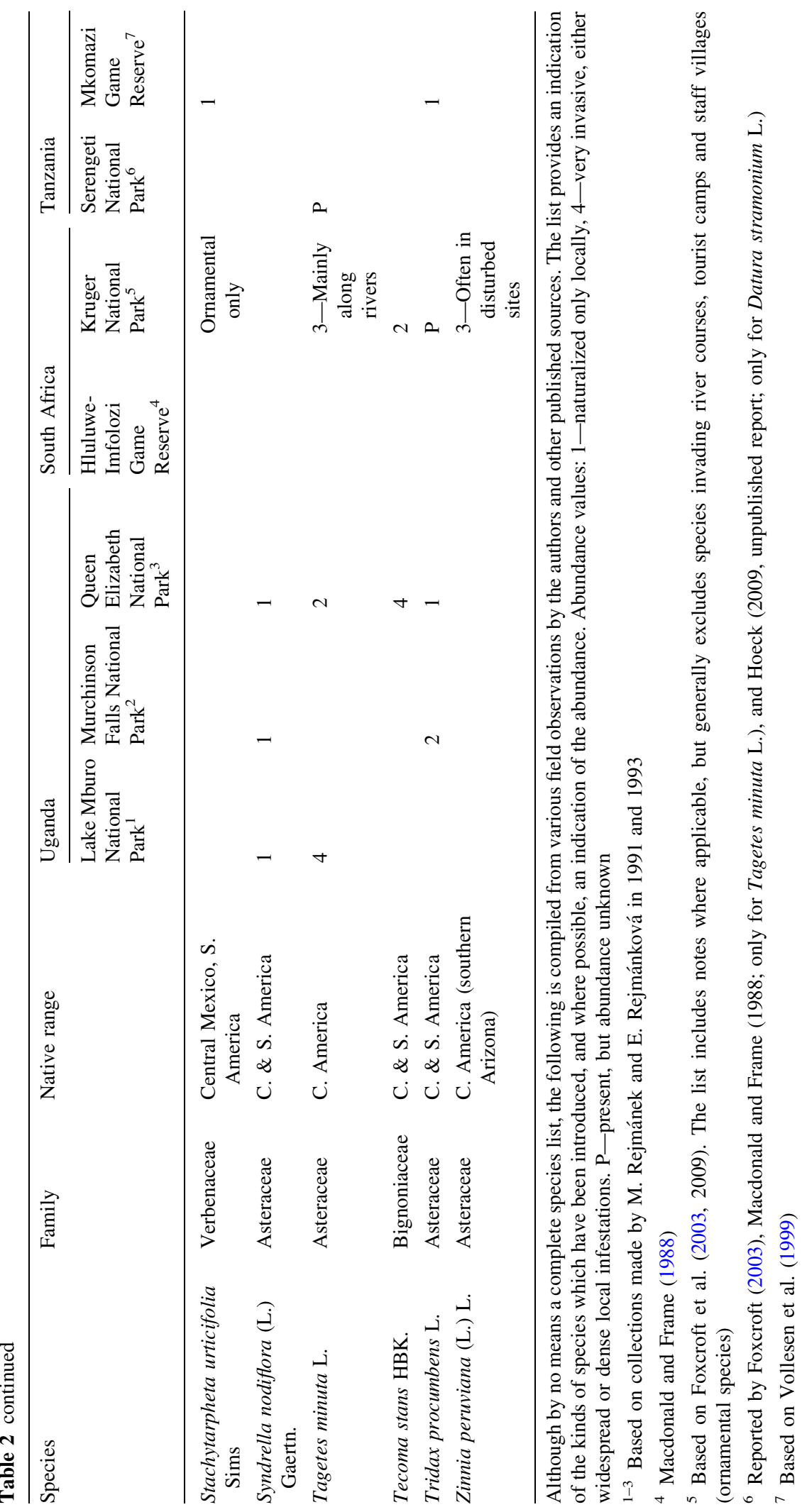


savannas to improve forage quality, have successfully spread and displaced native species. Assessing the physiological attributes of the Hyparrhenia rufa (Nees) Stapf. (Fig. 1g, h), a successful invader, they suggest that its success is due to its water-stress evasion strategy, larger biomass allocation to leaves, high germination rates and fast seedling growth. Additionally, $\mathrm{C}_{4}$ grasses are also known to have higher nitrogen-use efficiencies (NUE) than $\mathrm{C}_{3}$ species (Brown 1978; Snaydon 1991), thus adding further competitive ability.

In assessing the effects of invasive alien plants on fire regimes, Brooks et al. (2004) discuss the role of African grasses in Venezuelan savannas, which increase biomass by up to $50 \%$. Similarly, Imperata cylindrica (L.) P. Beauv. in south-eastern USA pine savannas increases fuel loads enormously (Richardson et al. 2007b). Rejmánek et al. (2005) state that savannas, especially disturbed deforested areas in the Neotropical regions, are very often dominated by African grasses such as Hyparrhenia rufa and Melinis minutiflora P. Beauv., while similar tropical habitats in Africa (specifically the east African savannas) and Asia are dominated by Neotropical woody plants, such as Lantana camara and Opuntia spp.

In Brazil, a number of African grasses selected for high forage and seed production potential (Klink 1996) were intentionally introduced-a practice which was still encouraged in the late 1990s (Pivello et al. 1999a). Additionally, large areas were disturbed by ploughing, which provided opportunities for the introduced grasses to invade (Klink 1996). In an assessment of the impact of alien grasses in Brazilian savannas, Pivello et al. (1999a, b) contend that these introduced species had spread to such a magnitude that they are present and dominant in almost all cerrado fragments. The dominant species include Melinis minutiflora, Brachiaria (Urochloa) decumbens Stapf., Hyparrhenia rufa, Andropogon gayanus Kunth (Fig. 1c) and Panicum maximum Jacq. Some African grasses were reported to inhibit regeneration of trees in Neotropical savannas (Hoffman and Haridasan 2008). Further, in Columbia, Venezuela, and Brazil, Williams and Baruch (2000) reported that about 4 million $\mathrm{km}^{2}$ were transformed to pasture by using, to a large extent, African $\mathrm{C}_{4}$ grasses. The tree Calotropis gigantea R.Br. (Crown flower) is described as "the most aggressive phytoinvader" in the Caatinga biome of Brazil (Cavalcante and Major 2006).

\section{Alien plant invasions in Australian savannas}

African bunchgrasses and European annual grasses are common alien species in Australia (D'Antonio and Vitousek 1992), with the history of planned plant introductions (Lonsdale 1994) dating back to the 1880s (Mott 1986). Lonsdale (1994) reports that 466 pasture species were intentionally introduced into the savannas of northern Australian and at least 13\% of these species have become invasive. Their invasiveness is most likely due to these species being predominantly selected as vigorous competitors, hardy and mostly of savanna origin. Thus, the intentional introduction of species has greatly enhanced the status of invasive species in particular areas. However, it appears that the estimate by Lonsdale (1994) might be an underestimate, as Cook and Dias (2006) show that over 70 years more than 8,200 species were introduced into cultivation in the country by Australia's Commonwealth Plant Introduction Scheme.

Andropogon gayanus (Fig. 1c) is one of the most noxious invasive plant species in Australian tropical savannas; this invasion has led to several-fold increases in the fuel load and fire intensity in northern Australian savannas (Rossiter et al. 2003). Introduced as a pasture grass in about the 1930s, A. gayanus has spread across the northern areas of Australia (Flores et al. 2005). It inhibits soil nitrification and thereby depletes total soil nitrogen from the already nitrogen-poor soils and promotes firemediated nitrogen loss (Rossiter-Rachor et al. 2009). Combined with the altered fire regime, it forms selfperpetuating positive feedback loops (Rossiter-Rachor et al. 2009). We return to the role of fire as a mechanism of invasion in a later section. Besides fire regime altering grasses from Africa or Asia (e.g., Andropogon gayanus, Cenchrus ciliaris, Pennisetum polystachion, Themeda quadrivalvisFig. 1d), several woody species are also invading Australian savannas (Acacia nilotica from Africa, Cryptostegia grandiflora from Madagascar, Jatropha gossypifolia from C. America, Lantana camara from the Neotropics, Mimosa pigra from S. America, Parkinsonia aculeata from S. America, Prosopis spp. 
from Americas, Ziziphus mauritiana from India) (Fenshaam et al. 1994; Grice et al. 2000; Grice 2004). However, perhaps the most difficult are more than 10 cactus species introduced from Central and South America (Hosking et al. 1988).

\section{Mechanisms at play: reasons for lower rates of invasion in Africa}

Biological invasions are increasing in extent and impact globally, threatening the integrity and functioning of ecosystems (Sala et al. 2000; Millennium Ecosystem Assessment 2005; Mooney et al. 2005), yet little scientific evidence of naturalization and impacts has emanated from African savannas. D'Antonio and Vitousek (1992) stated that, for example, alien grass invasions could be found on all continents, although examples from Africa (and Eurasia) are rare. Much of what has been written is based on observations mainly in southern Africa and South Africa in particular (for example, Brown and Gubb 1986; Henderson and Wells 1986; FreitagRonaldson and Foxcroft 2003). This could be contrasted with the book World Savannas (Mistry 2000) where invasive plants are discussed in four places: invasive African grasses in Brazilian cerrado, African grasses in Venezuelan llanos, and invasive plants in Australian savannas. There is, however, also a short discussion about invasive plants in South African savannas, based on Henderson and Wells (1986) chapter in Macdonald et al. (1986) and on Richardson et al. (1997). Invasive plants are not even mentioned in the chapter on savannas in West or East Africa.

In the volume Biodiversity and Savanna Ecosystem Processes (Solbrig et al. 1996), plant invasions are discussed in two chapters. One chapter discusses ecophysiological aspects of the invasion by African grasses, and their impact on biodiversity (Baruch 1996) and the other biodiversity and stability in tropical savannas (Silva 1996). Importantly however, only invasions in Neotropical savannas are discussed in both cases. Interestingly, Baruch (1996) states that African grasses had been introduced since colonial times, both accidentally and deliberately. He however attributed the widespread invasions to the more recent introductions of grasses introduced for pasture 'improvement'. He further contends that the species richness and structural diversity of the natural grasslands had been lost and turned into "closed, species-poor, homogeneous stands" (Baruch 1996).

Does this mean that Africa savannas are more resistant to plant invasions (i.e. do particular features of the habitat confer resistance), or that the particular species that have been introduced are less aggressive invaders? Surely some areas or patches must be as invasible as in other savannas? Similarly, a wide range of species have been introduced, into a range of areas, many of which are known invaders elsewhere in similar habitats. Therefore it is unlikely that there are no species that possess the traits needed to invade in some areas. Alternatively, invasions may be widespread, but not adequately reported across much of Africa, where invasions have been markedly understudied with the exception of South Africa (Pyšek et al. 2008). Species introduced recently for agroforestry are an example of where species are known to be potentially invasive, or have already started spreading, but such invasions are too recent to be well covered in the literature. Moreover, we should remember that, in general, much less is known about plant invasions in the tropics than in temperate zones (Ramakrishnan 1991; Rejmánek 1996; Denslow and DeWalt 2008). In the next section (also see Table 3) we offer some potential explanations for the patterns described above.

\section{Herbivore presence/absence}

In temperate grassland biomes, those areas that are more vulnerable to alien plant invasions lack large mammalian grazers to affect selection in perennial grasses (Mack 1989). These include Australia, South America and parts of the USA. Native grasses in the New World were not adapted to heavy mammalian grazing pressure and associated disturbances, having had a long absence of mammalian grazers (Mack 1989). Thus, under the influence of cattle introduced during human colonization, grasses introduced from Eurasia which had adapted to large, congregating mammalian grazers over a long period, were well suited to invading the New World territories (Kimball and Schiffman 2003). In North America, bison occurred in large herds in the Great Plains, but were absent from a number of areas such as California's central valley since the late Pleistocene $(12,000$ years ago; Edwards 1992). Additionally, bison have been functionally absent from American savannas and 
Table 3 A summary of the roles of seven factors potentially influencing alien plant invasions in three major savanna systems

\begin{tabular}{|c|c|c|c|}
\hline Factor & Africa & Neotropics & Australia \\
\hline Herbivore presence & Very high & Very low & Low \\
\hline $\begin{array}{l}\text { Time since introduction } \\
\text { (lag phase) }\end{array}$ & $\begin{array}{l}\text { Most in last } 100 \text { years, but } \\
\text { Opuntia ficus-indica dates } \\
\text { back to } 1770 \mathrm{~s}\end{array}$ & Long, dating back to $1500 \mathrm{~s}$ & $\begin{array}{l}\text { Recent (since about } 1850 \text { s for } \\
\text { northern Australia) }\end{array}$ \\
\hline $\begin{array}{l}\text { Intentional introduction } \\
\text { (pasture planting) }\end{array}$ & None & High & Very high \\
\hline Widely planted for pasture & None & Very high & High \\
\hline Fire & $\begin{array}{l}\text { Very high frequency. } \\
\text { Vegetation fire adapted }\end{array}$ & Low, minor role in ecosystem & $\begin{array}{l}\text { Frequent but with low intensity } \\
\text { fire; but Andropogon gayanus } \\
\text { significantly increases fuel load, } \\
\text { fire intensity and frequency of } \\
\text { fires }\end{array}$ \\
\hline $\begin{array}{l}\text { Resistance; resistance to } \\
\text { species naturalisation is } \\
\text { probably conferred by } \\
\text { increased numbers of } \\
\text { barriers to invasion }\end{array}$ & $\begin{array}{l}\text { Unknown; Opuntia spp. well } \\
\text { adapted to invasion in arid } \\
\text { African systems due to } \\
\text { CAM photosynthesis }\end{array}$ & $\begin{array}{l}\text { Unknown; but possibly overcome } \\
\text { by ploughing disturbance, } \\
\text { widespread planting, and } \\
\text { preadaptation of African grasses } \\
\text { (e.g., Hyparrhenia rufa) }\end{array}$ & $\begin{array}{l}\text { Unknown, but possibly overcome } \\
\text { by pasture planting. Also, } \\
\text { Andropogon gayanus forms } \\
\text { positive self-reinforcing } \\
\text { feedback loops in the N cycle }\end{array}$ \\
\hline Anthropogenic disturbance & $\begin{array}{l}\text { High levels of grazing by } \\
\text { cattle and goats. Fire was } \\
\text { used frequently for } \\
\text { providing fresh grass and } \\
\text { other reasons }\end{array}$ & High & Livestock grazing \\
\hline $\begin{array}{l}\text { Physiology of introduced } \\
\text { species }\end{array}$ & $\begin{array}{l}\text { CAM photosynthesis of } \\
\text { Opuntia spp. introduced to } \\
\text { Africa }\end{array}$ & $\begin{array}{l}\text { The success of introduced African } \\
\text { C4 grasses is suggested to be } \\
\text { due to their water-stress evasion } \\
\text { strategy, larger biomass } \\
\text { allocation to leaves, high } \\
\text { germination rates, fast seedling } \\
\text { growth and higher nitrogen use } \\
\text { efficiencies }\end{array}$ & Bunch grass growth form \\
\hline
\end{tabular}

grasslands since about 1880 (Knapp et al. 1999), and their numbers declined substantially before this date. Not only did this result in a loss of herbivory pressure, but a substantial shift in the functioning of these savanna ecosystems (Knapp et al. 1999). This period coincides with some prominent invasions of Eurasian grasses in North American perennial grasslands and shrublands, such the invasion of Bromus tectorum L. This annual grass was disseminated during the building of the transcontinental railway and it is estimated that $200,000 \mathrm{~km}^{2}$ were invaded between 1890 and 1930s (Mack 1989). In Australia the largest indigenous grazers are the eastern grey and red kangaroos, and South America also lacks large congregating grazers.

This is certainly not the case across the savannas of Africa. Large herds of a variety of species are characteristic features of African savannas, and include substantial numbers of mega-herbivores and bulk grazers (Sinclair and Norton-Griffiths 1979; Owen-Smith 1988; Sinclair and Arcese 1995; du Toit et al. 2003). Thus herbivores could conceivably suppress naturalization of alien plant species. In addition to ungulates and mega-herbivores, insect herbivory and effect of pathogens are likely to be important. Insect and pathogen damage on alien plants in African savannas may not differ from that of other savanna systems, but may act in concert with the pressure from large mammals. In a controlled study, Agrawal and Kotanen (2003) showed that alien plants suffered leaf attack levels that were the same, or higher, than those experienced by congeneric native plants. Similarly, Maron and Vilà (2001) suggested that native herbivores can reduce the likelihood of plant growth of the introduced species, as well as seed set and survive.

Another important consideration is whether the changes in herbivory pressure, both in space and time, 
are likely to impart increased or decreased resistance to invasion. However, because so little is known of the role of herbivores in influencing invasibility of ecosystems, any attempts to discuss the changes in herbivory would be conjecture at this stage.

Propagule pressure: intentional introductions and widespread pasture plantings

One of the most striking features of the invasion of Australian savannas is the abundance of species that were intentionally introduced for pasture enhancement and other reasons (Lonsdale 1994; Cook and Dias 2006). Similar patterns exist for the Neotropics (Baruch and Bilbao 1999). These species were not only intentionally introduced in high numbers, but actively dispersed and sown in a wide range of areas. Further, in many cases species selected for importation were selected for the same traits that would promote invasion (Anderson et al. 2006). However, there are no records of the same trend in the African savanna systems. This is probably as a result of the already abundant forage and browse (of sufficiently good quality) present to maintain large numbers of wild ungulates and domestic stock. Thus repeated introductions of large quantities of propagules were unlikely. This also presents a rare opportunity for African countries to ensure that policies are put in place to prevent similar introductions. Although the continent's rich grass flora, which is also adapted to the pressures of the region (herbivory by large mammals and fire), is unlikely to be invaded by grasses from other areas due caution is however still required. Milton (2004) suggests that, for South Africa at least, the winter rainfall and arid regions already show signs of increasing grass invasions, while the summer rainfall areas are likely to be invaded in wetlands and riparian areas.

Economic pressures are an enormous additional factor driving the intentional introduction of pasture grasses and other species. For example, intensive cattle grazing practices could not be sustained in the tropical America's without the introduction of African grasses (D'Antonio and Vitousek 1992). This is another likely cause of differences in the levels of invasion between Africa and South America (and probably also Australia). Tropical South American savannas are among the most important resources in the region, and probably globally, for cattle production (Lascano 1991).
However, the soils are commonly extremely acidic and have low nutrient levels (Sánchez and Isabell 1979). The higher productivity of African $C_{4}$ grasses is derived from their tolerance to high temperatures, drought, and ability to grow on acid, nutrient poor soils that are typical of most of tropical America (D'Antonio and Vitousek 1992). In areas of improved pasture (using alien species), production per unit area (typically beef cattle production) can be increased by as much as 10 times (Lascano 1991). Therefore the economic incentive to extend the areas sown with alien species was and still is high.

The role of herbivory in preventing or at least limiting the invasion by alien plants has not been well studied in the tropics (Dawson et al. 2009). The 'enemy release hypothesis' states that highly invasive alien plants suffer less herbivory that less invasive plants (Dawson et al. 2009). Ungulate herbivory (the role of insect herbivores was generally under-appreciated) was considered an important factor in limiting plant invasions in South Africa's Kruger National Park (Macdonald 1988). For example, Macdonald (1988) observed that Nicotiana glauca R.C. Graham and Ricinus communis only occurred in the KNP in areas protected from heavy grazing. Also, Macdonald (1988) reported that a small population of Acacia dealbata Link. growing along the banks of the Sabie River was eventually eliminated from the park through browsing pressure. Vegetation in African savannas has evolved with humans (and their livestock), high grazing and browsing pressure by wild ungulates, and fire (D'Antonio and Vitousek 1992), thus becoming highly adapted and tolerant to fire (see van Wilgen et al. 2007 for a discussion of the effects of fire).

The time since introduction (residence time) and the potential "lag-phase" that often precedes widespread invasions cannot be excluded as a possible explanation for the lower levels of invasion in African savannas to date. Residence time has shown to be a crucial factor in determining a species' abundance and distribution (Rejmánek 2000; Pyšek and Jarošík 2005; Wilson et al. 2007). However, as it appears that intentional introductions were kept to a minimum, and information on accidental introductions is largely unknown, it is difficult to factor in the role of residence time as even approximate dates of introduction are not known for most regions.

In a global review of plant invasions Lonsdale (1999) stated that savannas are among the least 
invaded biomes globally. However, there was considerable within-group variation. Further, work by Humphries et al. (1991) in Australia, and Lonsdale (1999; a global review) suggests that there are real differences in the degree of invasion between biomes, which might lead one to conclude, for example, that deserts and savannas are less invasible. However, Lonsdale (1999) additionally suggests that these results cannot be interpreted without, at least, rough estimates of propagule pressure.

\section{History and biogeography}

A general pattern that emerges at this time is that Africa and Australia have mostly been invaded by Cactaceae from the Neotropics, whereas Australia and the Neotropics have been mainly invaded by African $\mathrm{C}_{4}$ grasses. This is probably proportional to species pools (Cactaceae are, with exception of one species, the New World family and there are very likely more $\mathrm{C} 4$ grass species in Africa than in any other continent), pre-adaptation of CAM photosynthesis in the Cactaceae to dry tropics, the physiological attributes of African $\mathrm{C}_{4}$ grasses and, the extent of savanna systems in Africa. In comparison, Australia did not provide many invasive species to other parts of the world, except for Acacia spp. in Africa (and elsewhere), but these are mostly invasive in temperate regions of the continent, and mostly in South Africa (Nel et al. 2004).

The historical context is also important; people from Africa were transported to the Americas as early as the 1500 s and 1600s as slaves, and undoubtedly transported various plants with them (Kull and Rangan 2008). For example, African grasses were used as bedding in slave ships (Parsons 1972) and food crops such as African rice accompanied these movements (Carney 2003). Thus, species such as Melinis minutiflora and Hyparrhenia rufa were first described from Brazil and not from their native areas.

\section{Fire}

Fire is an important process in savanna ecosystems (van Wilgen et al. 2007), where it removes high amounts of fast accumulating material (Bond and Keeley 2005), and facilitates the coexistence of trees and grasses (Higgins et al. 2000). The evolution of African savannas with fire (of both natural and anthropogenic ignition sources), has long been accepted by ecologists as a predictable and common feature (Bond et al. 2005; Sankaran et al. 2008). Fire has further been suggested as an important evolutionary force shaping biomes (Bond and Keeley 2005) and a key factor in splitting species into fire tolerant and intolerant areas, and thereby maintaining $\mathrm{C}_{4}$ grasslands and savannas in their state (Bond et al. 2005).

Fire can filter and suppress those potentially invasive species that are poorly adapted to the fire regime into which they are moved. Alternatively, fires may promote invasions by disadvantaging native grasses (Grace et al. 2001). For example, many of the grasses which were introduced to and subsequently invaded the Neotropics and Australia are $\mathrm{C}_{4}$ bunchgrasses which are well adapted to fire. There are many examples of how invasive alien grasses interacted with fire to alter various ecosystem processes (for example see Vitousek 1990; D’Antonio and Vitousek 1992; D'Antonio 2000). In the northern Australian savannas the invasion of Andropogon gayanus has increased fuel loads, the intensity, extent and frequency of fires (Rossiter-Rachor et al. 2009). These impacts further resulted in a four-fold increase in biomass and the above-ground pools of nutrients, and therefore a general depletion of soil nutrients, specifically nitrogen (Rossiter-Rachor et al. 2009). Other mechanisms of invasion-fire mediated changes include the establishment of new plant forms (from wooded savanna to grassland) which may have intrinsic fuel properties that differ from those of native species (Brooks et al. 2004). This may change the window of fire activity by either shortening or lengthening the fire season, as well as change surface to canopy fire patterns (and vice versa).

\section{Conclusions: Are African savannas resistant to plant invasions?}

Our review suggests that African savannas are less severely invaded than those on other continents. Likely reasons for this are (1) the lack of intentional grass species introductions in most areas of Africa compared to the Neotropics and Australia, where introductions for 'pasture improvement' were major contributors to invasions in savanna ecosystems; (2) resistance of native African grasses to grazing and disturbances associated with grazing, acquired during 
evolutionary history by selection from large herbivores that were missing from analogous Neotropical and Australian ecosystems; (3) historical and biogeographical reasons of the origin of introduced species, and (4) the adaptation of African systems to fire (Table 3). Among the key differences between the seasonally dry vegetation of Africa and the Neotropics are the longer history of human occupation and animal domestication and the greater frequency of fire in Africa and the much more diverse mammal fauna in Africa that did not suffer major extinctions during Pleistocene (Lock 2006).

However, it needs to be borne in mind that invasions by alien species are poorly reported across Africa, besides South Africa and other localised areas (Pyšek et al. 2008). The lack of complete species lists, distribution data and information on introduction dates and history of individual invasions makes generalization difficult. For example, data on naturalised woody species, which are likely to be increasing in extent, is highly fragmented (Richardson et al. 2004). Since the invasibility of an ecosystem cannot be rigorously evaluated without accounting for confounding factors such as propagule pressure (Lonsdale 1999; Chytrý et al. 2008a, b; Pyšek et al. 2010), it is even more difficult to draw conclusions of whether African savannas are inherently more resistant to invasion by alien species.

It is also possible that the invasions described in the literature on savannas focus on densely invaded areas with substantial impacts, which might be limited in extent. Therefore, to obtain deeper insight into the global patterns of invasions in savannas, further research is needed to (1) obtain accurate and objective inventories of alien plant species from representative regions within the savanna biomes; (2) assess the role that these species play in savanna ecosystems, also in relation to native species diversity; and (3) develop proxies for propagule pressure based on historical and economic data to assess the relationship between introduction intensity and extent of invasion. Such data would facilitate rigorous testing of hypotheses associated with the observed patterns and pave the way for an unbiased picture of the invasibility of savanna ecosystems in different parts of the world.

The review would not be complete without speculating on how global environmental change may alter the status and dynamics of plant invasions in savannas.
Changing levels of $\mathrm{CO}_{2}$ are likely to be important drivers of change. Atmospheric $\mathrm{CO}_{2}$ has already risen by $30 \%$ in the past century, from $\sim 275 \mathrm{ppm}$ to about 370-375 ppm in 2005 (Keeling and Whorf 2001; Solomon et al. 2007) and 430 ppm currently (Stern 2007). Concentrations of around $550 \mathrm{ppm}$ are expected by 2035 (Stern 2007), with 700 ppm predicted by the end of the current century (Houghton et al. 1996). Although there is little data on the expected changes in the invasiveness of alien species specifically (Ziska 2003; Walther et al. 2009), recent studies provide us with indications that changes will be momentous. $\mathrm{C}_{4}$ plants are thought to have evolved in hot regions of the world in response to decreasing atmospheric $\mathrm{CO}_{2}$ (Ehleringer 2005; Sage 2004). By the middle of this century, $\mathrm{CO}_{2}$ concentrations will have exceeded the threshold at which $\mathrm{C}_{4}$ plants have a photosynthetic advantage over $\mathrm{C}_{3}$ species (Bond 2008). This potentially means that the invasion of African $\mathrm{C}_{4}$ grasses in the Neotropics and Australian savannas could become less important. In grasslands and savannas across Africa, rapid increase in the use of woody alien species for commercial forestry and especially agroforestry, suggests that a number of species already introduced and widely dispersed are likely to become highly invasive (see for example Table 13.1 in Richardson et al. 2000). In combination with the traits of many of these species which make them inherently invasive (Richardson et al. 2004), elevated $\mathrm{CO}_{2}$ could greatly improve their persistence in the ecosystems they invade, exacerbating their negative impacts. However, there are other factors that should be considered. For example, the recent analysis of 161 savanna sites in Africa (Sankaran et al. 2008) concluded that there is a strong negative dependence of woody cover on soil nitrogen availability, suggesting that increased anthropogenic $\mathrm{N}$-deposition may cause shifts in savannas towards more grassy communities. The only conclusion possible at this point is that altered precipitation regimes, elevated levels of $\mathrm{CO}_{2}$, and $\mathrm{N}$-enrichment will often end with opposing and interacting influences on the tree-grass balance in savannas. Whether native or exotic species will profit from such changes will be likely highly site specific.

Acknowledgments LCF and DMR acknowledge the DSTNRF Centre of Excellence for Invasion Biology. M. Rejmánek thanks the National Geographic Society. PP acknowledges 
support from the Academy of Sciences of the Czech Republic (grant no. AV0Z60050516) and the Ministry of Education, Youth and Sports of the Czech Republic (MSM0021620828 and LC06073). We thank Zuzana Sixtová for technical assistance.

Open Access This article is distributed under the terms of the Creative Commons Attribution Noncommercial License which permits any noncommercial use, distribution, and reproduction in any medium, provided the original author(s) and source are credited.

\section{References}

Agrawal AA, Kotanen PM (2003) Herbivores and the success of exotic plants: a phylogenetically controlled experiment. Ecol Lett 6:712-715

Anderson NO, Galatowitsch SM, Gomez N (2006) Selection strategies to reduce invasive potential in introduced plants. Euphytica 148:203-216

Archer S, Schimel DS, Holland EA (1995) Mechanisms of shrubland expansion: land-use, climate or CO2. Clim Chang 29:91-99

Asner GP, Archer S, Hughes RF, Ansley RJ, Wessman CA (2003) Net changes in regional woody vegetation cover and carbon storage in Texas drylands, 1937-99. Glob Chang Biol 9:316-335

Barthlott W, Lauer W, Placke A (1996) Global distribution of species diversity in vascular plants: towards a world map of phytodiversity. Erdkunde 50:317-327

Baruch Z (1996) Ecophysiological aspects of the invasion by African grasses and their impact on biodiversity. In: Solbrig OT, Medina E, Silva JF (eds) Biodiversity and savanna ecosystem processes. Ecological studies 121. Springer, Berlin, pp 79-96

Baruch Z, Bilbao B (1999) Effects of fire and defoliation on the life history of native and invader $\mathrm{C} 4$ grasses in a Neotropical savanna. Oecologia 119:510-520

Belsky AJ (1987) Revegetation of natural and human-caused disturbances in the Serengeti national Park, Tanzania. Vegetation 70:51-60

Bond WJ (2008) What limits trees in $\mathrm{C}_{4}$ grasslands and savannas? Annu Rev Ecol Evol Syst 39:641-659

Bond WJ, Keeley JE (2005) Fire as a global 'herbivore': the ecology and evolution of flammable Ecosystems. Trends Ecol Evol 20:387-394

Bond WJ, Midgley GF (2000) A proposed $\mathrm{CO}_{2}$-controlled mechanism of woody plant invasion in grasslands and savannas. Glob Chang Biol 6:865-869

Bond WJ, Woodward FI, Midgley GF (2005) The global distribution of ecosystems in a world without fire. New Phytol 165:525-538

Bourlière F, Hadley M (1983) Present-day savannas: an overview. In: Bourlière F (ed) Ecosystems of the world 13. Tropical savannas. Elsevier, Amsterdam, pp 1-17

Brooks ML, D'Antonio CM, Richardson DM, Grace JB, Keeley JE, DiTomaso JM, Hobbs RJ, Pellant M, Pyke D (2004) Effects of invasive alien plants on fire regimes. Bioscience 54:677-688
Brown RI (1978) A difference in $\mathrm{N}$ use efficiency in $\mathrm{C}_{3}$ and $\mathrm{C}_{4}$ plants and its implications in adaptation and evolution. Crop Sci 18:93-98

Brown CJ, Gubb AA (1986) Invasive alien organisms in the Namib Desert, Upper Karoo and the arid and semi-arid savannas of western southern Africa. In: Macdonald IAW, Kruger FJ, Ferrar AA (eds) The ecology and management of biological invasions in Southern Africa. Oxford University Press, Cape Town, pp 93-108

Carney J (2003) The African antecedents of Uncle Ben in US rice history. J Hist Geog 29:1-21

Carter S, Radcliffe-Smith AR (1988) Euphorbiaceae (Part 2). In: Polhill RM (ed) Flora of tropical east Africa. A. A. Balkema, Rotterdam, pp 409-597

Cavalcante A, Major I (2006) Invasion of alien plants in the Caatinga biome. Ambio 35:141-143

Chytrý M, Jarošík V, Pyšek P, Hájek O, Knollová I, Tichý L, Danihelka J (2008a) Separating habitat invasibility by alien plants from the actual level of invasion. Ecology 89:1541-1553

Chytrý M, Maskell L, Pino J, Pyšek P, Vilà M, Font X, Smart S (2008b) Habitat invasions by alien plants: a quantitative comparison between Mediterranean, subcontinental and oceanic regions of Europe. J Appl Ecol 45:448-458

Coe M, McWilliams N, Stone G, Packer M (eds) (1999) Mkomazi: the ecology, biodiversity and conservation of a Tanzanian savanna. Royal Geographical Society, London

Cole MM (1986) The savannas. Biogeography and geobotany. Academic Press, Brace Javanovich Publishers, Harcourt, London

Cook GD, Dias L (2006) It was no accident: deliberate plant introductions by Australian government agencies during the $20^{\text {th }}$ century. Aust J Bot 54:601-625

Coutinho LM (1978) O conceito de cerrado. Revista Brasileira de Botânica São Paulo 1:115-117

Coutinho LM (1982) Ecological effects of fire in Brazilian cerrado. In: Huntley BJ, Walker BH (eds) Ecology of tropical savannas. Springer, Berlin, pp 273-291

Cowling RM, Richardson DM, Schulze RE, Hoffman MT, Midgley JJ, Hilton-Taylor C (1997) Species diversity at the regional scale. In: Cowling RM, Richardson DM, Pierce SM (eds) Vegetation of Southern Africa. Cambridge University Press, Cambridge

D'Antonio CM (2000) Fire, plant invasions, and global changes. In: Mooney HA, Hobbs RJ (eds) Invasive species in a changing world. Island Press, Washington, D.C., pp 65-93

D’Antonio CM, Vitousek PM (1992) Biological invasions by exotic grasses, the grass/fire cycle, and global change. Annu Rev Ecol Syst 23:63-87

Dawson W, Burslem DFRP, Hulme PE (2009) Herbivory is related to taxonomic isolation, but not to invasiveness of tropical alien plants. Divers Distrib 15:144-147

Denslow JS, DeWalt SJ (2008) Exotic plant invasions in tropical forests: patterns and hypotheses. In: Carson WP, Schnitzer SA (eds) Tropical forest community ecology. Wiley-Blackwell, Chichester, pp 409-426

du Toit JT, Rogers KH, Biggs HC (eds) (2003) The Kruger experience, ecology and management of savanna heterogeneity. Island Press, Washington D.C.

Dupont LM, Jahns S, Marret F, Ning S (2000) Vegetation change in equatorial West Africa: time-slices for the last 
150 ka. Palaeogeogr Palaeoclimatol Palaeoecol 155: 95-122

Edwards SW (1992) Observations on the prehistory and ecology of grazing in California. Fremontia 20:3-11

Ehleringer JR (2005) The influence of atmospheric $\mathrm{CO}_{2}$, temperature, and water on the abundance of $\mathrm{C}_{3} / \mathrm{C}_{4}$ taxa. In: Ehleringer JR, Cerling TE, Dearing MD (eds) A history of atmospheric $\mathrm{CO}_{2}$ and its effects on plants, animals, and ecosystems. Springer, New York, pp 185-213

Eiten G (1972) The cerrado vegetation of Brazil. Bot Rev 38:201-341

Eiten G (1983) Classificação da Vegetação do Brasil. Brasília: Conselho Nacional de Desenvolvimento Científico e Tecnológico $(\mathrm{CNPq})$

Fenshaam RJ, Fairfax RJ, Cannell RJ (1994) The invasion of Lantana camara L. in Forty Mile Scrub National Park, North Queensland. Aust J Ecol 19:297-305

Flores TA, Setterfield SA, Douglas MM (2005) Seedling recruitment of the exotic grass Andropogon gayanus in northern Australia. Aust J Bot 53:1-7

Foxcroft LC (2003) Observations and recommendations for the management of invasive alien plant species in Serengeti National Park. A report to the Serengeti National Park, Tanzania

Foxcroft LC (2009) A list of alien plants in the Kruger National Park. Unpublished records, South African National Parks, South Africa

Foxcroft LC, Freitag-Ronaldson S (2007) Seven decades of institutional learning: managing alien plant invasions in the Kruger National Park, South Africa. Oryx 41:160-167

Foxcroft LC, Rejmánek M (2007) What helps Opuntia stricta invade Kruger National Park, South Africa: Baboons or elephants? Appl Veg Sci 10:265-270

Foxcroft LC, Richardson DM (2003) Managing alien plant invasions in Kruger National Park, South Africa. In: Child LE, Brock JH, Brundu G, Prach K, Pyšek P, Wade PM, Williamson M (eds) Plant invasions: ecological threats and management solutions. Backhuys, Leiden, pp 385-403

Foxcroft LC, Henderson L, Nichols GR, Martin BW (2003) A revised list of alien plants for the Kruger National Park. Koedoe 46:21-44

Foxcroft LC, Rouget M, Richardson DM, MacFadyen S (2004) Reconstructing 50 years of Opuntia stricta invasion in the Kruger National Park, South Africa: environmental determinants and propagule pressure. Divers Distrib 10:427-437

Foxcroft LC, Rouget M, Richardson DM (2007) Risk assessment of riparian plant invasions into protected areas. Conserv Biol 21:412-421

Foxcroft LC, Richardson DM, Wilson JRU (2008) Ornamental plants as invasive aliens: problems and solutions in the Kruger National Park, South Africa. Environ Manage 41:32-51

Freitag-Ronaldson S, Foxcroft LC (2003) Anthropogenic influences at the ecosystem level. In: du Toit JT, Rogers $\mathrm{KH}$, Biggs HC (eds) The Kruger experience, ecology and management of savanna heterogeneity. Island Press, Washington D.C., pp 391-421

Furley P (2006) Tropical savannas. Prog Phys Geogr 30: $105-121$
Germishuizen G, Meyer NL (eds) (2003) Plants of Southern Africa: an annotated checklist. National Botanical Institute, Pretoria

Gillson L (2004) Evidence of hierarchical patch dynamics in an East African savanna? Landsc Ecol 19:883-894

Grace JB, Smith MD, Grace SL, Collins SL, Stohlgren TJ (2001) Interactions between fire and invasive plants in temperate grasslands of North America. In Galley KEM, Wilson TP (eds) Proceedings of the Invasive Species Workshop: the role of fire in the control and spread of invasive species. Fire Conference 2000: the First National Congress on Fire Ecology, Prevention, and Management. Miscellaneous Publication No. 11, Tall Timbers Research Station, Tallahassee, FL, pp 40-65

Grice AC (2004) Weeds and the monitoring of biodiversity in Australian rangelands. Austral Ecol 29:51-58

Grice AC, Radford IJ, Abbott BN (2000) Regional and landscape-scale patterns of shrub invasion in tropical savannas. Biol Invasions 2:187-205

Harrison YA, Shackleton CM (1999) Resilience of South African communal grazing lands after the removal of high grazing pressure. Land Degrad Dev 10:225-239

Henderson L (2002) Problem plants in Ngorongoro Conservation Area. A report to the Ngorongoro Conservation Areas Authority, Tanzania

Henderson L (2007) Invasive, naturalized and casual alien plants in southern Africa: a summary based on the Southern African Plant Invaders Atlas (SAPIA). Bothalia 37:215-248

Henderson L, Wells MJ (1986) Alien plant invasions in the grassland and savanna biomes. In: Macdonald IAW, Kruger FJ, Ferrar AA (eds) The ecology and management of biological invasions in southern Africa. Oxford University Press, Cape Town, pp 109-117

Higgins SI, Bond WJ, Trollope WSW (2000) Fire, resprouting and variability: a recipe for grass-tree coexistence in savanna. J Ecol 88:213-229

Hoffman WA, Haridasan M (2008) The invasive grass, Melinis minutiflora, inhibits tree regeneration in a Neotropical savanna. Austral Ecol 33:29-36

Hoffmann MT, Todd S (2000) A national review of land degradation in South Africa: the influence of biophysical and socio-economic factors. J S Afr Stud 26:743-758

Hosking JR, McFadyen RC, Murray ND (1988) Distribution and biological control of cactus species in eastern Australia. Plant Prot Quart 3:115-122

Houghton JT, Meira-Filho LG, Callander BA, Harris N, Kattenburg A, Maskell K (1996) IPCC climate change assessment 1995: the science of climate change. Cambridge University Press, Cambridge

Huber O, Riina R (eds) (2003) Glosario Fitoecológico de las Américas, vol 1 \& 2. UNESCO, Paris

Humphries SE, Groves RH, Mitchell DS (1991) Plant invasions of Australian ecosystems: a status review and management directions. Kowari 2:1-134

Huntley BJ (1982) Southern African savannas. In: Huntley BJ, Walker BH (eds) Ecology of tropical savannas. Ecological studies 42. Springer, Berlin, pp 101-119

Huntley BJ, Walker BH (eds) (1982) Ecology of tropical savannas. Ecological studies 42. Springer, Berlin 
Jeník J, Hall JB (1976) Plant communities of Accra Plains, Ghana. Folia Geobotanica Phytotaxonomica 11:163-212

Keeling CD, Whorf TP (2001) Atmospheric $\mathrm{CO}_{2}$ records from sites in the SIO air sampling network. In: Trends: a compendium of data on global change. Carbon Dioxide Information Analysis Center, US Department of Energy, Oak Ridge National Laboratory, Oak Ridge, TN, USA

Kimball S, Schiffman PM (2003) Differing effects of cattle grazing on native and alien plants. Conserv Biol 17:16811693

King SE, Grace JB (2000) The effects of gap size and disturbance type on invasion of wet pine savanna by cogongrass, Imperata cylindrica (Poaceae). Am J Bot 87: 1279-1286

Klink CA (1996) Germination and seedling establishment of two native and one invading African grass species in the Brazilian cerrado. J Trop Ecol 12:139-147

Knapp AK, Blair JM, Briggs JM, Collins SL, Hartnett DC, Johnson LC, Gene Towne E (1999) The keystone role of bison in North American tallgrass prairie. Bioscience 49:39-50

Kull CA, Rangan H (2008) Acacia exchanges: wattles, thorn trees, and the study of plant movements. Geoforum 39:1258-1272

Lascano CE (1991) Managing the grazing resource for animal production in savannas of tropical America. Trop Grass 25:66-72

Lehmann CER, Ratnam J, Hutley LB (2009) Which of these continents is not like the other? Comparisons of tropical savanna systems: key questions and challenges. New Phytol 181:508-511

Lock JM (2006) The seasonally dry vegetation of Africa: parallels and comparisons with the Neotropics. In: Pennington RT, Lewis GP, Ratter JA (eds) Neotropical savannas and seasonally dry forests-plant diversity, biogeography, and conservation. CRC Press, Boca Raton, pp 449-467

Long SP, Garcia Moya E, Imbamba SK, Kamnalrut A, Piedade MTF, Scurlock JMO, Shen YK, Hall DO (1989) Primary productivity of natural grass ecosystems of the tropics: a re-appraisal. Plant Soil 115:155-166

Lonsdale WM (1994) Inviting trouble: introduced pasture species in Northern Australia. Aust J Ecol 19:345-354

Lonsdale WM (1999) Global patterns of plant invasions and the concept of invasibility. Ecology 80:1522-1536

López-Olmedo LI, Meave JA A, Pérez-García EA (2007) Floristic and structural contrasts between natural savannas and anthropogenic pastures in a tropical dry landscape. Rangeland J 29:181-190

Lyons EE, Miller SE (eds) (1999) Invasive species in eastern Africa. In: Proceedings of a workshop held at ICIPE, July 5-6. ICIPE Science Press, Kenya

Macdonald IAW (1983) Alien trees, shrubs and creepers invading indigenous vegetation in the Hluhluwe Umfolozi Game Reserves Complex in Natal. Bothalia 14: 949-959

Macdonald IAW (1988) The history, impacts and control of introduced species in the Kruger National Park, South Africa. Trans R Soc S Afr 46:251-276
Macdonald IAW, Frame GW (1988) The invasion of introduced species into nature reserves in tropical savannas and dry woodlands. Biol Conserv 44:67-93

Macdonald IAW, Kruger FJ, Ferrar AA (eds) (1986) The ecology and management of biological invasions in southern Africa. Oxford University Press, Cape Town

Mack RN (1989) Temperate grasslands vulnerable to plant invasions: characteristics and consequences. In: Drake JA, Mooney HA, Di Castri F, Groves F, Kruger FJ, Rejmánek M, Williamson M (eds) Biological invasions: a global perspective. John Wiley, New York, pp 155-179

Maron JL, Vilà M (2001) When do herbivores affect plant invasion? Evidence for the natural enemies and biotic resistance hypotheses. Oikos 95:361-373

Melillo JM, McGuire AD, Kicklighter DW, Moore B, Vorosmarty CJ, Schloss AL (1993) Global climate change and terrestrial net primary production. Nature 363:234-240

Mies B, Jimenez MS, Morales D (1996) Ecophysiology and distribution of the endemic leafless spurge Euphorbia aphylla and the introduced E. tirucalli (Euphorbiaceae) in the Canary Islands. Plant Syst Evol 202:27-36

Millennium Ecosystem Assessment (2005) Ecosystems and human well-being: biodiversity synthesis. World Resources Institute, Washington D.C.

Milton SJ (2004) Grasses as invasive alien plants in South Africa. S Afr J Sci 100:69-75

Milton SJ, Wilson JRU, Richardson DM, Seymour CL, Dean WRJ, Iponga DM, Procheş Ş (2007) Invasive alien plants infiltrate bird-mediated shrub nucleation processes in arid savanna. J Ecol 95:648-661

Mistry J (2000) World savannas: ecology and human use. Prentice Hall, Harlow

Mooney HA, Mack RN, McNeely JA, Neville LA, Schei PJ, Waage JK (eds) (2005) Invasive alien species: a new synthesis. Island Press, Washington, D.C

Mott JJ (1986) Planned invasions of Australian tropical savannas. In: Groves RH, Burdon JJ (eds) Ecology of biological invasions. Cambridge University Press, Sydney, pp 89-96

Nel JL, Richardson DM, Rouget M, Mgidi T, Mdzeke N, Le Maitre DC, van Wilgen BW, Schonegevel L, Henderson L, Neser S (2004) A proposed classification of invasive alien plant species in South Africa: towards prioritising species and areas for management action. S Afr J Sci 100:53-64

Owen-Smith N (1988) Megaherbivores. The influence of very large body size on ecology. Cambridge University Press, Cambridge

Pandey DS (2000) Exotics-introduced and natural immigrants, weeds, cultivated. In: Singh NP, Singh DK, Hajra PK, Sharma BD (eds) Flora of India, introductory volume, Part II. Botanical Survey of India, Calcuta, pp 266-301

Parsons JJ (1972) Spread of African pasture grasses to the American tropics. J Range Manage 25:12-17

Pickett STA, Cadenasso ML, Benning TL (2003) Biotic and abiotic variability as key determinants of savanna heterogeneity at multiple spatiotemporal scales. In: du Toit JT, Rogers KH, Biggs HC (eds) The Kruger experience, ecology and management of savanna heterogeneity. Island Press, Washington D.C., pp 22-40 
Pivello VR, Shida CN, Meirelles ST (1999a) Alien grasses in Brazilian savannas: a threat to the biodiversity. Biodivers Conserv 8:1281-1294

Pivello VR, Carvalho VMC, Lopes PF, Peccinini AA, Rosso S (1999b) Abundance and distribution of native and alien grasses in a "Cerrado" (Brazilian Savanna) biological reserve. Biotropica 31:71-82

Pyšek P, Jarošík V (2005) Residence time determines the distribution of alien plants. In: Inderjit (ed) Invasive plants: ecological and agricultural aspects. Birkhäuser Verlag-AG, Basel, pp 77-96

Pyšek P, Richardson DM (2006) The biogeography of naturalization in alien plants. J Biogeogr 33:2040-2050

Pyšek P, Richardson DM, Rejmánek M, Webster G, Williamson M, Kirschner J (2004) Alien plants in checklists and floras: towards better communication between taxonomists and ecologists. Taxon 53:131-143

Pyšek P, Richardson DM, Pergl J, Jarošík V, Sixtová Z, Weber E (2008) Geographical and taxonomical biases in invasion biology. Trends Ecol Evol 23:237-244

Pyšek P, Chytrý M, Jarošík V (2010) Habitats and land-use as determinants of plant invasions in the temperate zone of Europe. In: Perrings C, Mooney HA, Willimason M (eds) Bioinvasions and globalization: ecology, economics, management and policy. Oxford University Press, Oxford, pp 66-79

Ramakrishnan PS (ed) (1991) Ecology of biological invasions in the tropics. International Scientific Publications, New Delhi

Rejmánek M (1996) Species richness and resistance to invasions. In: Orians G, Dirzo R, Cushman JH (eds) Biodiversity and ecosystem processes in tropical forests. Springer, New York, pp 153-172

Rejmánek M (2000) Invasive plants: approaches and predictions. Austral Ecol 25:497-506

Rejmánek M, Richardson DM, Pyšek P (2005) Plant invasions and invasibility of plant communities. In: van der Maarel E (ed) Vegetation ecology. Blackwell, Oxford, pp 332-355

Richardson DM, Macdonald IAW, Hoffmann JH, Henderson L (1997) Alien plant invasions. In: Cowling RM, Richardson DM, Pierce SM (eds) Vegetation of Southern Africa. Cambridge University Press, Cambridge, pp 535-570

Richardson DM, Pyšek P, Rejmánek M, Barbour MG, Panetta FD, West CJ (2000) Naturalization and invasion of alien plants: concepts and definitions. Divers Distrib 6:93-107

Richardson DM, Binggeli P, Schroth G (2004) Invasive agroforestry trees: problems and solutions. In: Schroth G, de Fonseca GAB, Harvey CA, Gascon C, Vasconcelos H, Izac A-MN (eds) Agroforestry and biodiversity conservation in tropical landscapes. Island Press, Washington, D.C., pp 371-396

Richardson DM, Holmes PM, Esler KJ, Galatowitsch SM, Stromberg JC, Kirkman SP, Pyšek P, Hobbs RJ (2007a) Riparian vegetation: degradation, alien plant invasions, and restoration prospects. Divers Distrib 13:126-139

Richardson DM, Rundel PW, Jackson ST, Teskey RO, Aronson J, Bytnerowicz A, Wingfield MJ, Procheş S (2007b) Human impacts in pine forests: past, present and future. Ann Rev Ecol Evol Syst 38:275-297
Rogers KH (2003) Adopting a heterogeneity paradigm: implications for management of protected areas. In: du Toit JT, Rogers KH, Biggs HC (eds) The Kruger experience, ecology and management of savanna heterogeneity. Island Press, Washington, D.C., pp 41-58

Roques KG, O'Conner TG, Watkinson AR (2001) Dynamics of shrub encroachment in an African savanna: relative influences of fire, herbivory, rainfall and density dependence. J Appl Ecol 38:268-280

Rossiter NA, Setterfield SA, Douglas MM, Hutley LB (2003) Testing the grass-fire cycle: alien grass invasion in the tropical savannas of northern Australia. Divers Distrib 9:169-176

Rossiter-Rachor NA, Setterfield SA, Douglas MM, Hutley LB, Cook GB, Schmidt S (2009) Invasive Andropogon gayanus (gamba grass) is an ecosystem transformer of nitrogen relations in Australian savanna. Ecol Appl 19:1546-1560

Sage RF (2004) The evolution of $\mathrm{C}_{4}$ photosynthesis. New Phytol 161:341-370

Sala OE et al (2000) Global biodiversity scenarios for the year 2100. Science 287:1770-1774

Sánchez PA, Isabell RF (1979) A comparison of the soils of tropical Latin America and tropical Australia. In: Sánchez PA, Tergas LE (eds) Proceedings of a seminar on pasture production in acid soils of the tropics, Cali, Colombia, 1978. CIAT, Cali, pp 25-54

Sankaran M, Hanan NP, Scholes RJ et al (2005) Determinants of woody cover in African Savannas. Nature 438:846-849

Sankaran M, Ratnam J, Hanan N (2008) Woody cover in African savannas: the role of resources, fire and herbivory. Glob Ecol Biogeogr 17:236-245

Schmitz A (1971) La vegetation de la Plaine de Lubumbashi (Haut-Katanga). Publications de l'Institut National pour l'Étude Agronomique du Congo, Bruxelles

Scholes RJ (1997) Savanna. In: Cowling RM, Richardson DM, Pierce SM (eds) Vegetation of Southern Africa. Cambridge University Press, Cambridge, pp 258-277

Scholes RJ, Archer SR (1997) Tree-grass interactions in savannas. Annu Rev Ecol Syst 28:517-544

Scholes RJ, Walker BH (1993) An African savanna: synthesis of the Nylsvley study. Cambridge University Press, Cambridge

Shorrocks B (2007) The biology of African savannas. Oxford University Press, Oxford

Sillans R (1958) Les savannes de l'Afrique Centrale. Editions Paul Lechevalier, Paris

Silva JF (1996) Biodiversity and stability in tropical savannas. In: Solbrig OT, Medina E, Silva JF (eds) Biodiversity and savanna ecosystem processes. Ecological studies 121. Springer, Berlin, pp 161-174

Sinclair ARE, Arcese P (eds) (1995) Serengeti II: dynamics, management and conservation of an ecosystem. University of Chicago Press, Chicago

Sinclair ARE, Norton-Griffiths M (eds) (1979) Serengeti: dynamics of an ecosystem. University of Chicago Press, Chicago

Sinclair ARE, Packer C, Muduma SAR, Fryxell JM (eds) (2008) Serengeti III: human impacts on ecosystem dynamics. University of Chicago Press, Chicago 
Snaydon RW (1991) The productivity of C3 and C4 plants: a reassessment. Funct Ecol 5:321-330

Solbrig OT, Medina E, Silva JF (eds) (1996) Biodiversity and savanna ecosystem processes. Ecological studies 121. Springer, Berlin

Solomon S, Qin D, Manning M, Chen Z, Marquis M, Averyt KB, Tignor M, Miller HL (eds) (2007) Contribution of Working Group I to the Fourth Assessment Report of the Intergovernmental Panel on Climate Change. Cambridge University Press, Cambridge

Stern N (2007) The economics of climate change. The Stern review, Part III: the economics of climate change. Cambridge University Press, Cambridge

Tongway DJ, Ludwig JA (2005) Heterogeneity in arid and semi-arid lands. In: Lovett GM, Jones CG, Turner MG, Weathers KC (eds) Ecosystem function in heterogeneous landscapes. Springer, USA, pp 189-205

Turpie J (2004) The role of resource economics in the control of invasive alien plants in South Africa. S Afr J Sci 100:87-93

Van Auken OW (2000) Shrub invasions of North American semiarid grasslands. Annu Rev Ecol Syst 31:197-215

van Wilgen BW, Richardson DM, Le Maitre DC, Marias C, Magadlela D (2001) The economic consequences of alien plant invasions: examples of impacts and approaches to sustainable management in South Africa. Environ Dev Sustain 3:145-168

van Wilgen BW, Govender N, Biggs HC (2007) The contribution of fire research to fire management: a critical review of a long-term experiment in the Kruger National Park, South Africa. Int J Wildl Fire 16:519-530

Vitousek PM (1990) Biological invasions and ecosystem processes: toward an integration of population biology and ecosystem studies. Oikos 57:7-13

Vollesen K, Abdallah R, Coe M, Mboya E (1999) Checklist: vascular plants and pterridophytes of Mkomazi. In: Coe M, McWilliams N, Stone G, Packer M (eds) Mkomazi: the ecology, biodiversity and conservation of a Tanzanian savanna. Royal Geographical Society, London, pp 80-116

Walker BH, Noy-Meir I (1982) Aspects of the stability and resilience of savanna ecosystems. In: Huntley BJ, Walker $\mathrm{BH}$ (eds) Ecology of tropical savannas. Ecological studies 42. Springer, Berlin, pp 556-590

Walker BH, Ludwig D, Holling CS, Peterman RM (1981) Stability of semi-arid grazing systems. J Ecol 69:473-498

Walther GR, Roques A, Hulme PE, Sykes M, Pyšek P, Kühn I, Zobel M, Bacher S, Botta-Dukát Z, Bugmann H, Czúcz B, Dauber J, Hickler T, Jarošík V, Kenis M, Klotz S, Minchin D, Moora M, Nentwig W, Ott J, Panov VE, Reineking B, Robinet C, Semenchenko V, Solarz W, Thuiller W, Vilà M, Vohland K, Settele J (2009) Alien species in a warmer world: risks and opportunities. Trends Ecol Evol 24:686-693

Werner PA (ed) (1991) Savanna ecology and management: Australian perspectives and intercontinental comparisons. Blackwell, Melbourne

Whitehead PJ, Woinarski J, Jacklyn P, Fell D, Williams D (2000) Defining and measuring the health of savanna landscapes: a north Australian perspective. Tropical Savannas CRC Discussion Paper, Australia

Wigley BJ, Bond WJ, Hoffmann TM (2009) Bush encroachment under three contrasting land-use practices in a mesic South African savanna. Afr J Ecol 47:62-70

Williams DG, Baruch Z (2000) African grass invasion in the Americas: ecosystem consequence and the role of ecophysiology. Biol Invasions 2:123-140

Wilson JRU, Richardson DM, Rouget M, Procheş Ş, Amis MA, Henderson L, Thuiller W (2007) Residence time and potential range: crucial considerations in modelling plant invasions. Divers Distrib 13:11-22

Ziska LH (2003) Evaluation of the growth response of six invasive species to past, present and future atmospheric carbon dioxide. J Exp Bot 54:395-404 